\title{
Spontaneous Diabetes in BB Rats: Evidence for a T Cell Dependent Immune Response Defect
}

\author{
D. Bellgrau ${ }^{*, 3}$, A. Naji, ${ }^{1}$ W. K. Silvers, ${ }^{2}$ J. F. Markmann, ${ }^{1}$ and C. F. Barker ${ }^{1}$ \\ Departments of ${ }^{1}$ Surgery, ${ }^{2}$ Human Genetics and the ${ }^{3}$ Immunobiology Research Unit, University of Pennsylvania, \\ Philadelphia, Pennsylvania, USA
}

\begin{abstract}
Summary. Approximately $50 \%$ of BB rats develop insulinopenic hyperglycaemia and ketosis spontaneously in association with insulitis. Amelioration of the syndrome by immunosuppression suggests a cell mediated immune pathogenesis. Analysis of the cell-mediated immune profile of overtly diabetic and normoglycaemic diabetes prone $\mathrm{BB}$ rats indicates that they are lymphocytopenic relative to non-diabetes prone $\mathrm{BB}$ rats and that the $T$ cell pool is particularly affected. Furthermore, lymphocytes from diabetic and diabetes prone BB rats, while producing normal responses to the $\mathrm{T}$ cell mitogen concanavalin $\mathrm{A}$,
\end{abstract}

do not respond when mixed in vitro with major histocompatibility complex incompatible lymphocytes. This anergy is not restored either by enriching the responding cell population for $T$ cells or by adding exogenous $T$ cell growth promoting factor. Thus $B B$ rats have a numerical and regulatory deficit of their $T$ cells which could be related to their propensity for diabetes.

Key words: Spontaneous diabetes, BB rats, immunodeficiency, T lymphocytopenia, mixed lymphocyte culture, immunoregulatory deficit.
The possibility that an immune mediated destruction of islet cells is responsible for Type 1 (insulin-dependent) diabetes has been suggested by the increased association of this disease with certain autoimmune endocrinopathies [1], as well as by the characteristic mononuclear infiltration of the endocrine pancreas observed in patients with this malady [2]. The fact that susceptibility to the disease is linked to certain cell surface determinants coded by genes located in the major histocompatibility complex (HLA-DR3 and DR4) further supports an immunological aetiology [3]. This complex is known to control several facets of immunological responses including allograft rejection and cell-cell interactions between subsets of immunocompetent cells [4].

Of all spontaneously diabetic animal models, the BB rat is the most pertinent since these animals have several features in common with Type I human diabetes. BB rats are not obese, and approximately 50\% develop spontaneously an insulinopenic hyperglycaemia and ketosis associated with lymphocytic infiltration of their islets (insulitis) between 60 and 180 days of age. Selective breeding increases the incidence of the disease [5]. An immune actiology is also suggested by the fact that neonatal thymectomy or immunosuppression with anti-lym-

\footnotetext{
* Present address: Basel Institute for Immunology, Grenzacherstraße 487, CH-4058, Basel, Switzerland
}

phocyte serum effectively prevents hyperglycaemia and in the case of the latter even reverses it [6-8].

Therefore, we have studied cell mediated immunity in several lines of these animals. The experiments which form the basis for this report are focused on evaluating $T$ cell function in BB rats.

\section{Materials and Methods}

\section{Rats}

Genetically uniform Lewis (L) (RT-1 ${ }^{\text {l}}$ ), Wistar-Furth (WF) (RT-1 $\left.{ }^{\text {un}}\right)$, DA $\left(\right.$ RT-1 $\left.{ }^{n}\right)$, Brown Norway (BN) $\left(\mathrm{RT}^{-1}{ }^{\mathrm{n}}\right)$ and August (Aug) $\left(\mathrm{RT}-1^{\mathrm{c}}\right)$ rats were bred in our own animal colony.

Our initial stock of BB rats was obtained from Bio Breeding Laboratories (thus BB) of Canada, Ottawa, Ontario, in 1977. Random breeding of these animals (which were originally derived from a closed colony of heterogeneous Wistar rats) and their descendants over a 15 month period resulted in 28 additional litters ( 300 rats). The overall incidence of diabetes in these rats was $18.3 \%$. Since July 1979 , non-diabetic males and females of this BB stock have been selected and mated. This selection has resulted in producing some 45 litters ( 400 rats) in which only one rat developed the disease. Since this stock has been virtually diabetes free for five to six successive generations, it has been designated as a non-diabetes prone BB subline.

The second breeding nucleus of BB rats was obtained in July 1979 , from the Canadian Health and Welfare Department of the Sir Frederick Banting Research Center (which had taken over the BB colony of the Bio Breeding Laboratories). This second shipment included 48 rats, representing six litters derived from different breeding lines. Forty-one 
of these rats developed diabetes (87\%). Brother and sister matings of descendants of this second shipment has been continued so that ultimately an isogenic strain can be obtained. Since almost all the rats in this subline are descendants of the original diabetic nucleus (41 rats), it has been designated as the diabetes prone subline. The incidence of diabetes in litters produced by matings from this subline varies from $26 \%$ to $100 \%$. Hyperglycaemic animals within this subline are designated as diabetic BB rats.

Because intentional inbreeding of BB rats has been initiated only recently, the animals used in this study were not genetically uniform. Nevertheless, serological and mixed lymphocyte culture typing classify all $\mathrm{BB}$ rats as $\mathrm{RT}^{\mathrm{u}}$, the same major histocompatibility complex (RT1) haplotype as WF rats [8-10]. Moreover, $60 \%$ of skin grafts exchanged between randomly selected $\mathrm{BB}$ rats were retained for $>$ 100 days, indicating that members of the colony are closely related $[9$, $10]$.

\section{Diagnosis and Treatment of Diabetes}

Between 60 and 180 days of age BB rats were screened weekly for diabetes (plasma glucose > $11.1 \mathrm{mmol} / 1$, though it was rarely < $19.4 \mathrm{mmol} / \mathrm{l}$ in affected animals). Diabetic rats were maintained with a single daily injection of $3-5$ units of protamine zinc insulin.

\section{Lymphocyte Populations}

Lymphocytes were obtained from lymph nodes, spleen and thoracic duct lymph as described previously [11]. Separation of lymphocytes into adherent ( $T$ cell depleted) and non-adherent ( $T$ cell enriched) fractions was performed by passage of cells through nylon wool columns [12].

\section{TCell Growth Factor}

$\mathrm{T}$ cell growth factor was prepared from concanavalin A activated rat splenic lymphocytes as described by Gronvik and Andersson [13]. Concanavalin A activity was neutralized by the addition of $\alpha$-methylD-mannoside $(10 \mathrm{mg} / \mathrm{ml})$ or eliminated by passage over a Sephadex G100 column.

\section{Culture Conditions}

Analytical unidirectional mixed lymphocyte cultures were established in triplicate in Linbro 96 well U-bottom microtitre plates. Varying concentrations of responding cells (thoracic duct lymphocytes, 6,3 or 1.5 $\times 10^{5} / \mathrm{ml}$ ) were cocultured with irradiated (1700 rads) stimulator cells (lymph node, $\left.3 \times 10^{5}\right)$ in culture media $(0.2 \mathrm{ml})$. Culture media was RPMI - 1640 supplemented with glutamine $(2 \mathrm{mmol} / \mathrm{l})$, penicillin $(100 \mathrm{IU} / \mathrm{ml})$, streptomycin $(100 \mu \mathrm{g} / \mathrm{ml})$, Hepes buffer $(10 \mathrm{mmol} / \mathrm{l}), 2$ mercaptoethanol $(40 \mu \mathrm{mol} / \mathrm{l})$ and $5 \%$ mixed normal rat serum. Plates were incubated at $37^{\circ} \mathrm{C}$ in a humidified atmosphere containing $5 \%$ $\mathrm{CO}_{2}$. Proliferation of the responding lymphocytes was measured by the incorporation of ${ }^{3} \mathrm{H}$-thymidine $(0.25 \mu \mathrm{Ci} /$ well $)$ during the last $12 \mathrm{~h}$ of 4 day culture for mixed lymphocyte reaction and 3 day culture for concanavalin A induced cell proliferation as described previously [14].

Concanavalin A activated lymphocyte cultures were set up at a final optimal concentration of $7.5 \mu \mathrm{g} / \mathrm{ml}$ and under the same conditions as for mixed lymphocyte cultures.

\section{Anti-T and Anti-B Antibodies}

The alloantiserum, anti-Pta (an alloantigenic marker expressed on rat peripheral $\mathrm{T}$ cells) is specifically cytolytic for rat peripheral $\mathrm{T}$ cells in the presence of complement [15]. The monoclonal mouse anti-mouse $\mathrm{IaA}^{\mathrm{K}}$ antibody is rat $\mathrm{B}$ cell specific $[16,17]$. The frequency of $\mathrm{B}$ and $\mathrm{T}$ cells were determined in a complement dependent analytical microcytotoxicity assay. Briefly, Ficoll-Hypaque purified lymph node lym- phocytes, $\left(25 \mu \mathrm{l}, 250 \times 10^{3}\right.$ cells $)$ were added to serially diluted anti-T or anti-B antibodies $(50 \mu \mathrm{l})$ and rabbit complement $(25 \mu \mathrm{l})$ added. Viability was assessed by trypan blue exclusion and values recorded as plateau lysis after correcting for background complement lysis [11, 14].

All results are presented as mean \pm SD and statistical analysis are calculated using a two-tailed Wilcoxon rank sum test.

\section{Results}

\section{Lymphocytopenia}

The total lymphocyte count in various lymphoid compartments of non-diabetes prone BB rats was comparable with those found in a variety of normal inbred rat strains (Table 1). However, BB rats of the diabetes prone subline were consistently lymphocytopenic compared with those of the non-diabetes prone subline (or with rats of normal strains). Moreover, the reduction of the total lymphocyte count in BB rats of the diabetes prone subline was observed at all ages (1-12 months) regardless of whether they became diabetic or not.

\section{Specific Decrease in TLymphocytes}

In a complement dependent microcytotoxicity assay, using anti-T and anti-B antibodies, the frequency of $B$ and $T$ cells was assessed in diabetic, diabetes prone and nondiabetes prone BB rats. The percentage of $\mathrm{T}$ cells (in lymph nodes) identified serologically in diabetic and

Table 1. Lymphocyte content of various lymphoid compartments

\begin{tabular}{|c|c|c|c|c|}
\hline \multirow[t]{2}{*}{ Group } & \multirow[t]{2}{*}{ Rat strain } & \multicolumn{3}{|c|}{$\begin{array}{l}\text { Total number of lymphocytes } \\
\text { harvested }\left(\times 10^{6}\right)\end{array}$} \\
\hline & & $\begin{array}{l}\text { Thoracic } \\
\text { duct }^{\text {a }}\end{array}$ & $\begin{array}{l}\text { Lymph } \\
\text { nodes }^{\text {b }}\end{array}$ & Spleen \\
\hline A & Non-BB $(n=5)$ & $630 \pm 134$ & $176 \pm 24$ & $204 \pm 37$ \\
\hline $\mathrm{B}$ & $\begin{array}{l}\text { Non-diabetes prone BB } \\
(n=11)\end{array}$ & $579 \pm 132^{c}$ & $202 \pm 27$ & $205 \pm 66$ \\
\hline $\mathrm{C}$ & $\begin{array}{l}\text { Diabetes prone BB } \\
(n=16)\end{array}$ & $167 \pm 59^{d}$ & $79 \pm 12$ & $143 \pm 98$ \\
\hline $\mathrm{D}$ & Diabetic BB $(n=9)$ & $73 \pm 61^{\mathrm{e}}$ & $37 \pm 30$ & $75 \pm 33$ \\
\hline
\end{tabular}

Results expressed as mean $\pm \mathrm{SD}$.

${ }^{a}$ First 24-h collection from a free-draining cannula; b All available lymph nodes (cervical, axillary and mesenteric) harvested; ${ }^{\mathrm{c}} p>$ 0.05 compared with group $\mathrm{A}$; ${ }_{\mathrm{d}, \mathrm{e}} p<0.001$ compared with groups $\mathrm{B}$ and $\mathrm{A} ;{ }^{\mathrm{e}} p<0.01$ compared with group $\mathrm{C}$

Table 2. Percentage of B and T lymphocytes in lymph node cell populations of $\mathrm{BB}$ rats

\begin{tabular}{lll}
\hline BB Line & B Lymphocytes & T Lymphocytes \\
\hline Non-diabetes prone & $48.0 \pm 6.4$ & $49.0 \pm 2.6$ \\
Diabetes prone & $72.0 \pm 2.6$ & $19.8 \pm 4.0$ \\
Diabetic & $68.3 \pm 3.0$ & $18.3 \pm 5.9$ \\
\hline
\end{tabular}

Results are expressed as mean \pm SD and represent plateau cytotoxicity $(1: 16-1: 64$ antibody dilution) of four separate experiments after correcting for background lysis 
Table 3. Primary mixed lymphocyte culture responses of BB and Wistar Furth rats to major histocompatibility complex compatible and incompatible stimulator cells

\begin{tabular}{|c|c|c|c|c|c|c|c|}
\hline \multirow{2}{*}{$\begin{array}{l}\text { Strain of origin of } \\
\text { responding cells }\left(6 \times 10^{5}\right. \\
\text { thoracic duct lymphocytes })\end{array}$} & \multirow{2}{*}{$\begin{array}{l}\text { Unstimulated } \\
\text { cultures }\end{array}$} & \multicolumn{6}{|c|}{ Strain of origin of stimulator cells $\left(3 \times 10^{5}\right.$ irradiated lymph node cells) } \\
\hline & & $\mathrm{BB}^{\mathrm{a}}$ & $\mathrm{WF}^{\mathrm{a}}$ & $\mathrm{BN}^{\mathrm{b}}$ & $\mathrm{DA}^{\mathrm{b}}$ & $\mathrm{AUG}^{\mathrm{b}}$ & $\mathbf{L}^{\mathrm{b}}$ \\
\hline Wistar Furth $(n=6)$ & $477 \pm 260$ & $543 \pm 4$ & $254 \pm 197$ & $35022 \pm 2400$ & $17127 \pm 2691$ & $23290 \pm 2154$ & $28494 \pm 10988$ \\
\hline Diabetic BB $(n=15)$ & $261 \pm 244$ & $249 \pm 132$ & $489 \pm 127$ & $616 \pm 612$ & $861 \pm \quad 493$ & $278 \pm 158$ & $950 \pm 914$ \\
\hline $\begin{array}{l}\text { Diabetes prone } B B \\
\quad(n=40)\end{array}$ & $425 \pm 312$ & $513 \pm 425$ & $427 \pm 148$ & $1112 \pm 972$ & $1776 \pm 1177$ & $946 \pm 516$ & $1573 \pm 1085$ \\
\hline $\begin{array}{l}\text { Non-diabetes prone } \\
\quad \operatorname{BB}(n=25)\end{array}$ & $728 \pm 508$ & $885 \pm 693$ & $671 \pm 539$ & $37897 \pm 5374$ & $27763 \pm 16607$ & $27859 \pm 17606$ & $33456 \pm 17536$ \\
\hline
\end{tabular}

Compatible $\left({ }^{a}\right)$ and incompatible $\left({ }^{b}\right)$ at the major histocompatibility complex with BB rats.

Values are the mean \pm SD c.p.m. of ${ }^{3} \mathrm{H}$-thymidine incorporation on day 4 of $(\mathrm{n})$ independent experiments (each in triplicate)

normoglycaemic rats of the diabetes prone subline (19\% and $20 \%$, respectively) was less than that in non-diabetes prone BB animals (49\%) (Table 2). Conversely, there was a concomitant increase in the number of B cells in such rats $(72 \%$ and $68 \%)$.

\section{TCell Dependent Responses In Vitro}

The proliferative responses of $T$ cells to alloantigens and to a $T$ cell mitogen were used to assess the function of $T$ lymphocytes in BB rats. The alloantigen-induced proliferative responses of thoracic duct lymphocytes from various sublines of BB rats were tested in vitro by unidirectional mixed lymphocyte cultures (a T cell dependent assay). The results indicated that while lymphocytes from non-diabetes prone BB and WF (non-BB control) rats produced a normal response to an array of major histocompatibility complex incompatible stimulator cells, the response of lymphocytes from either diabetic or normoglycaemic members of the diabetes prone BB subline was significantly reduced (Table 3 ). This depressed response was evident against several different stimulator haplotypes. Variation in the responding cell to stimulator cell ratio did not result in a significant proliferation of cells from diabetic or diabetes prone donors.

In contrast to the responses to allogeneic cells the proliferative response of lymph node lymphocytes from the three sublines of $\mathrm{BB}$ rats to the $\mathrm{T}$ cell mitogen, concanavalin A, was comparable (Table 4). However, when thoracic duct lymphocytes from any subline were used, the corresponding responses were lower in each group than for lymph node, a likely consequence of fewer accessory cells present in thoracic duct lymph.

\section{TCell Enrichment}

Since it was conceivable, though unlikely, that unresponsiveness of lymphocytes from diabetic and diabetes prone $\mathrm{BB}$ rats in mixed lymphocyte culture reactions was due to their having fewer than normal numbers of $T$ cells (and an altered B cell: T cell ratio), an attempt was made to enrich this population by passage through nylon wool columns [12]. Accordingly, various concentrations
Table 4. Responses of BB lymphocytes to concanavalin A

\begin{tabular}{lll}
\hline BB Line & $\begin{array}{l}{ }^{3} \mathrm{H}-\text { Thymidine incorporation } \\
\left.\text { (c. p. } \mathrm{m} . / 3 \times 10^{5} \text { cells }\right)\end{array}$ \\
\cline { 2 - 3 } & Thoracic duct & Lymph node \\
\hline Diabetic $(n=10)$ & $17088 \pm 2078$ & $44937 \pm 9229$ \\
Diabetes prone $(n=16)$ & $14858 \pm 1213$ & $57239 \pm 2833$ \\
Non-diabetes prone $(n=16)$ & $28599 \pm 17467$ & $42068 \pm 18724$ \\
\hline
\end{tabular}

Values are expressed as mean \pm SD of (n) independent experiments (each in triplicate) on day 3 of culture

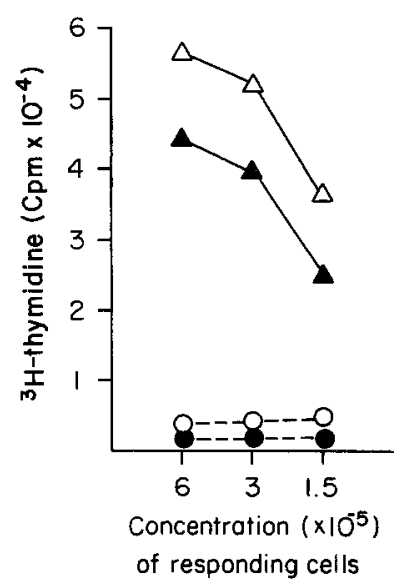

Fig. 1. Effect of alloantigen $\left(3 \times 10^{5}\right.$ irradiated lymph node cells from strain DA $\left(\mathrm{RT}^{\mathrm{a}}\right)$ ) on unfractionated and nylon wool fractionated T enriched lymphocytes from diabetes-prone and non-diabetes prone BB $\left(\mathrm{RT}^{\mathrm{u}}{ }^{\mathrm{u}}\right)$ rats. Diabetes prone (unfractionated -_- $\mathrm{T}$ - enriched $\mathrm{O}-\mathrm{O}$ ), non-diabetes prone (unfractionated $\boldsymbol{\Delta}-\boldsymbol{\Lambda}$ T enriched $\triangle-\triangle$ ). Points represent mean values of triplicate cultures for ${ }^{3} \mathrm{H}$ thymidine incorporation on day 4 of three separate experiments

$\left(6,3\right.$ or $\left.1.5 \times 10^{5}\right)$ of either unfractionated or nylon wool fractionated non-adherent ( $T$ cell enriched) thoracic duct lymphocytes from diabetes prone and non-diabetes prone BB rats were stimulated with $3 \times 10^{5}$ irradiated $\mathrm{DA}\left(\mathrm{RT}^{\mathrm{a}}{ }^{\mathrm{a}}\right.$ ) stimulator cells (Fig. 1). The T cell enriched lymphocyte population from non-diabetes prone animals produced an augmented response to alloantigen compared with unfractionated populations. On the other hand, the proliferative response of $\mathrm{T}$ cell enriched 


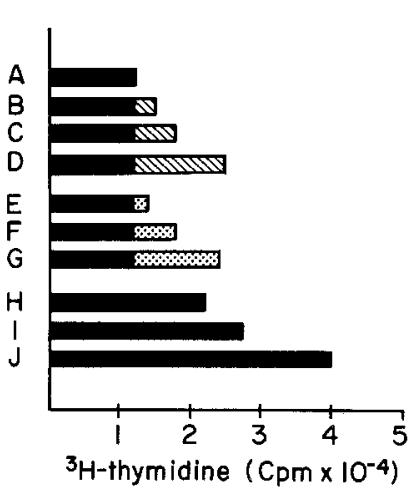

Fig. 2. Diabetic and diabetes prone lymphocytes do not suppress the mixed lymphocyte culture proliferation of non-diabetes prone cells. Row $\mathrm{A}$ is the matrix and represents the proliferative response of $1.5 \times$ $10^{5}$ non-diabetes prone thoracic duct lymphocytes to $3 \times 10^{5}$ irradiated strain Aug $\left(R T 1^{c}\right)$ stimulator cells. Rows B to J are the response when either $1.5,3$ or $6 \times 10^{5}$ of diabetes prone ( $\mathrm{N}, \mathrm{C}$, and D) diabetic ( $\mathrm{B}$, $F$ and $G$ ) or non-diabetes prone $(-\mathrm{H}, \mathrm{I}$, and J) lymphocytes were added to the matrix. Values are the mean of triplicate determinations of ${ }^{3} \mathrm{H}$-thymidine incorporation at day 4 from four separate experiments involving each $\mathrm{BB}$ line

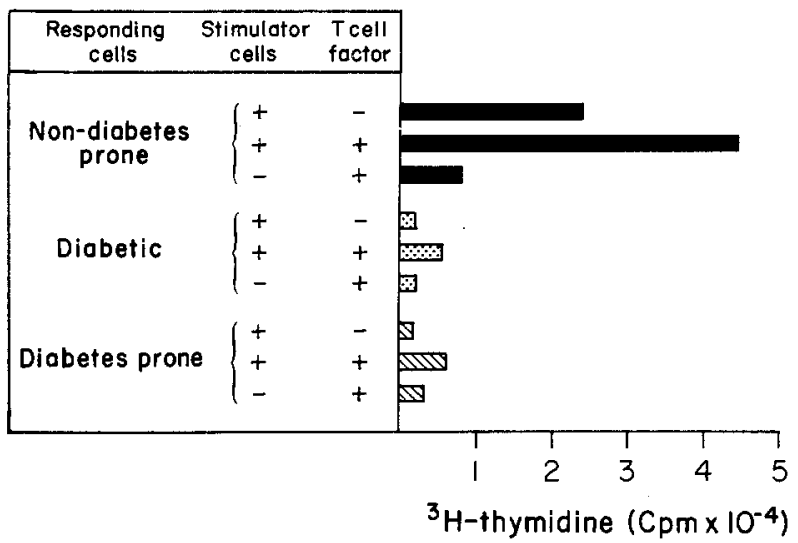

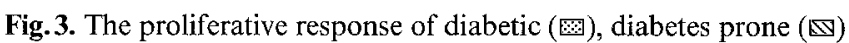
and non-diabetes prone $(-$ BB lymphocytes after the addition of $\mathrm{T}$ cell growth factor. Responding cells $\left(3 \times 10^{5}\right)$ from each BB line were cocultured with $3 \times 10^{5}$ irradiated strain Aug (RT1 $1^{c}$ ) stimulator cells alone or after addition of $50 \mathrm{ul}$ of $\mathrm{T}$ cell growth factor. Values represent the mean of ${ }^{3} \mathrm{H}$-thymidine uptake of triplicate cultures (day 4) from five independent experiments

lymphocytes from diabetes prone BB rats was not increased compared with the unfractionated cells.

\section{Cell Mixing Experiments}

Since mixed lymphocyte culture reactions from diabetic and normoglycaemic diabetes prone BB rats were anergic, it was important to determine whether they contained a subpopulation of suppressor cells which inhibited their proliferation in vitro. Accordingly, various concentrations $\left(6,3\right.$, or $\left.1.5 \times 10^{5}\right)$ of thoracic duct lymphocytes from diabetic and diabetes prone $\mathrm{BB}$ rats were added to a constant number $\left(1.5 \times 10^{5}\right)$ of non-diabetes prone lymphocytes in the presence of $3 \times 10^{5}$ irradiated
AUG (RT1 ${ }^{\circ}$ ) stimulator cells. Culturing of non-diabetes prone thoracic duct lymphocytes with irradiated AUG $\left(\mathrm{RT}^{c}{ }^{c}\right)$ lymph node cells under the same conditions resulted in a mean baseline ${ }^{3} \mathrm{H}$-thymidine incorporation of approximately 10,000 c.p.m. (row A, Fig. 2). In no instance did the addition of diabetic or diabetes prone lymphocytes suppress this response. In fact, addition of such cells augmented it. As expected, addition of non-diabetes prone lymphocytes greatly augmented proliferation, a fact consistent with the kinetics of this in vitro assay [14].

\section{Attempted Restoration of Mixed Lymphocyte Culture with TCell Growth Factor}

A possible explanation of the above augmented proliferative response is that non-diabetes prone lymphocytes activated in the mixed lymphocyte culture produce a $\mathrm{T}$ cell growth promoting factor which allows proliferation of antigen activated diabetic or diabetes prone lymphocytes, even though these cells themselves lack the capability of responding to allogeneic stimulator cells. To investigate this possibility attempts were made to restore the proliferative response of lymphocytes from such animals with $T$ cell growth factor.

Figure 3 depicts the results of five independent experiments in which thoracic duct lymphocytes from diabetic, diabetes prone and non-diabetes prone $\mathrm{BB}$ rats were assayed for their capacity to respond to irradiated allogeneic stimulators, to T cell growth factor alone, or to allogeneic stimulators in the presence of the $T$ cell growth factor. Although there was a significant increase in activity when $T$ cell growth factor was added to stimulator cells in the presence of cells from non-diabetes prone rats, diabetic and diabetes prone lymphocytes failed to respond in vitro either to $T$ cell growth factor alone or to allogeneic stimulator cells whether or not the factor was present.

\section{Discussion}

We have reported previously several observations suggesting that $\mathrm{BB}$ rats are immunologically deficient [10]. Compared with inbred rats of other strains, these rats have a high incidence of lymphoma [18], higher mortality from infections and a shortened life span (whether they become diabetic or not). Furthermore, these animals have an abnormally prolonged acceptance of skin allografts and histological examination of the spleen and lymph nodes of both diabetic and diabetes prone $\mathrm{BB}$ rats reveals a paucity of small lymphocytes in $T$ dependent zones while these areas are normal in non-diabetes prone $\mathrm{BB}$ rats [10].

Reported here are our initial attempts to analyse the functional cell mediated immune response capabilities of BB animals. Both overtly diabetic and diabetes prone normoglycaemic rats were found to be lymphocytopenic 
relative to non-diabetes prone BB rats or rats of other strains, and the T cell pool is particularly affected. Lymphocytes from diabetic and diabetes prone BB rats, while producing normal responses to the $\mathrm{T}$ cell mitogen concanavalin A, are seemingly unable by themselves to mount significant proliferative responses in vitro to major histocompatibility complex incompatible lymphocytes, a $\mathrm{T}$ cell dependent assay. This inability to respond to alloantigenic stimulation is not due to the decreased number of T cells in BB rats nor to a suppressor subset. Furthermore, a normal mixed lymphocyte culture response was not restored by the addition of exogenous $T$ cell growth promoting factors. There may be a correlation between the absence of a response in vitro to alloantigenic stimulation and the predisposition to diabetes, since lymphocytes from a BB subline bred and selected for a decreased incidence of the disease gave normal responses in vitro. The functional (as well as numerical) deficit in T lymphocytes of diabetes prone BB rats appears to be evident at all ages. Thus, 4 week-old (an age younger than that of earliest onset of diabetes) normoglycaemic rats of the diabetes prone subline were lymphocytopenic and mixed lymphocyte culture non-responsive, while lymphocytes from non-diabetes prone $\mathrm{BB}$ rats of the same age produced normal responses. Of 40 normoglycaemic diabetes prone $\mathrm{BB}$ rats studied, 10 eventually became diabetic between 2-20 weeks and 23 died between 3-30 weeks after the study commenced. The pancreas of 10 such normoglycaemic rats were examined histologically and no evidence of insulitis was found.

Two major issues raised by these data remain to be resolved: what is the exact nature and extent of the immune defect in diabetes prone BB rats and is this defect either directly or indirectly responsible for the disease? It has been shown in mice that helper T cells $(l y 1+)$ are required for optimal responses in mixed lymphocyte culture reactions [20]. A deficiency of these cells could therefore manifest itself in the form of a depressed mixed lymphocyte response. If a postulated helper defect is responsible for the abnormal mixed lymphocyte culture responses, it cannot be reconstituted with soluble factors alone as the addition of $\mathrm{T}$ cell growth factor failed to restore the response.

It is unlikely that the mixed lymphocyte culture hyporesponsiveness of diabetic or diabetes prone animals is due to any kind of suppression since in cell mixing experiments their cells do not suppress the proliferation of non-diabetes prone responding lymphocytes, but actually augment these responses. It may be that in the proper environment (a necessary requirement being viable cells from normal rats to reconstitute a helper defect) cells from diabetes prone animals might be able to proliferate. Perturbations in the immunological network may be the underlying cause of diabetes if autoimmunity is involved. In this regard, there is experimental evidence that $T$ cell immunoregulatory malfunction is a dominant factor in the aetiology of autoimmune diseases [21].
Several lines of evidence also suggest that normal T cell function confers protection against diabetes. This evidence includes our finding that members of a non-diabetes prone $\mathrm{BB}$ line have normal numbers of lymphocytes and normal proliferative responses in vitro to alloantigens. Secondly, $F_{1}$ hybrids between diabetic $B B$ rats and normal non-BB rats never become diabetic [10-19] and their cells invariably display a normal mixed lymphocyte culture response (unpublished observation). Finally, highly susceptible diabetes prone BB rats inoculated at birth with bone marrow from normal rats have a much reduced incidence of diabetes in adulthood [22] and display normal lymphocyte proliferation in vitro (unpublished data).

Nevertheless, despite these highly suggestive lines of reasoning, it remains to be ascertained whether the immunological debilitation of diabetes prone BB rats is causally related to their susceptibility to diabetes. It is possible that the occurrence of immune deficiency and of susceptibility to diabetes are entirely coincidental, or that the two traits are genetically linked, but with no causal relationship. Clearly only further investigations can determine that these factors are related.

Addendum. After the above studies were completed, we learned that similar results with respect to lymphocytopenia had been observed by Poussier et al. (Diabetologia 21:317, Abstract, 1981), and Jackson et al. (Diabetes 30:887-890, 1981).

Acknowledgments. We thank Dr. P. Thibert for providing our breeding nucleus of BB rats and Mr. G. Sawchuck and Ms. M. Naji for their excellent technical assistance. This work was supported by USPHS grants AM 26007, AM07314, CA15822, The Thomas McCabe Fund and the Reynolds Foundations.

\section{References}

1. Nerup J, Lernmark A (1981) Autoimmunity in insulin-dependent diabetes mellitus. Am J Med 70: 135-141

2. Gepts W, LeCompte P (1981) The pancreatic islets in diabetes. Am J Med 70: 105-115

3. Cudworth AG, Bottazzo GF, Doniah D (1981) Genetic and immunological factors in Type I diabetes. In: Irvine J (ed) Immunology of diabetes. Teviot, pp 67-99

4. McDevitt HO (1980) Regulation of the immune response by the major histocompatibility system. N Engl J Med 303: 1514-1517

5. Nakhooda AF, Like AA, Chappel CI, Wei CN, Marliss EB (1978) The spontaneously diabetic Wistar rat (the BB rat). Studies prior and during development of the overt syndrome. Diabetologia 14: 199-207

6. Like AA, Williams RM, Kislauskie E, Rossini AA (1981) Neonatal thymectomy prevents spontaneous diabetes in the $\mathrm{BB} / \mathrm{W}$ rat. Clin Res 29: Abstract 542A.

7. Like AA, Rossini AA, Guberski DL, Appel MC, Williams RM (1979) Spontaneous diabetes mellitus: reversal and prevention in the $\mathrm{BB} / \mathrm{W}$ rat with antiserum to rat lymphocytes. Science 206 : $1421-1423$

8. Naji A, Silvers WK, Barker CF (1981) Islet transplantation in spontaneously diabetic rats. Transplant Proc 13: 826-828

9. Naji A, Silvers WK, Plotkin SA, Dafoe D, Barker CF (1979) Successful islet transplantation in spontaneous diabetes. Surgery 86 : 218-226 
10. Naji A, Silvers WK, Bellgrau D, Anderson AO, Plotkin S, Barker, CF (1981) Prevention of diabetes in rats by bone marrow transplantation. Ann Surg 194: 328-338

11. Bellgrau D, Wilson DB (1978) Immunological studies of $T$ cell receptors. I. Specifically induced resistance to graft versus host disease in rats mediated by host $\mathrm{T}$ cells immune to alloreactive parental T cells. J Exp Med 148: 103-114

12. Julius MH, Simpson E, Herzenberg LA (1973) A rapid method for the isolation of functional thymus derived murine lymphocytes. Eur J Immunol 3: 645-649

13. Gronvik KO, Andersson J (1980) The role of T cell growth stimulating factor in $\mathrm{T}$ cell triggering. Immunol Rev 51:35-39

14. Wilson DB, Marshak A, Howard JC (1976) Specific positive and negative selection of rat lymphocytes reactive to strong histocompatibility antigens: Activation with alloantigen in vitro and in vivo. J Immunol 116: 1030-1040

15. Lubaroff DM, Greiner DL, Reynolds CW (1979) Investigation of T lymphocyte subpopulations in the rat using allogeneic markers. Transplant Proc 11: 1092-1094

16. Oi VT, Jones PP, Goding JW, Herzenberg LA (1978) Properties of monoclonal antibodies to mouse Ig allotypes, $\mathrm{H}-2$ and $\mathrm{I}^{\mathrm{a}}$ antigens. Curr Top Microbiol Immunol 81:115-119

17. Rozing J, Vaessen LMB, VanEwijk W, Lameijer LF (1979) Cross reactivity between mouse Ia antigens and rat Ia-like antigens as de- termined by monoclonal anti-mouse IaA ${ }^{k}$ antibodies. Transplant Proc 11: 1574-1578

18. Kalant N, Seemayer T (1979) Malignant lymphoma in spontaneously diabetic rats. N Eng J Med 200:737

19. Colle RD, Guttmann RD, Seemayer T (1981) Spontaneous diabetes mellitus syndrome in the rat. I. Association with the major histocompatibility complex. J Exp Med 154: 1237-1242

20. Cantor H, Boyse EA (1975) Functional subclasses of T lymphocytes bearing different Ly antigens. J Exp Med 141: 1390-1399

21. Cantor H, Gershon RK (1979) Immunological circuits: cellular composition. Fed Proc 38: 2058-2064

22. Naji A, Silvers WK, Bellgrau D, Barker CF (1981) Spontaneous diabetes in rats: Destruction of islets is prevented by immunological tolerance. Science 213: 1390-1392

Received: 16 September 1981

and in revised form: 20 May 1982

Dr. C.F. Barker

Department of Surgery

Hospital of the University of Pennsylvania

3400 Spruce Street

Philadelphia, PA 19104, USA 